\title{
SUSTAINABLE DESIGN, CONNECTIVITY ORDER AND DETAILING ARCHITECTURE TO SITE COMFORT, CORRIDOR BRAGA
}

\author{
Nurtati Soewarno $^{1 *}$, Taufan Hidjaz ${ }^{2}$, Eka Virdianti $^{3}$ \\ ${ }^{1,3}$ Department of Architecture, Institut Teknologi Nasional, Jl.PHH Mustafa 23 Bandung, INDONESIA \\ ${ }^{2}$ Department of Interior Design, Institut Teknologi Nasional, Jl.PHH Mustafa 23 Bandung, INDONESIA \\ *Corresponding author; Email: nurtati@itenas.ac.id
}

\begin{abstract}
Comfort in activities is very instrumental to liven up interaction within the city community. In fact, public spaces of a city are developed by the comfort obtained physically and psychically, Braga Corridor which built with the typology adapting the European and the tropical. This architecture is believed to provide fun experience for interaction, which eventually develop the physically comfort. Unfortunately that the city economy growth can threaten the existence of the Corridor. We believed the comfort fact to be the keyword to solve the problem. This study was aimed at analyzing connectivity and comfort. Mixed method research approach was employed. The data was gathered by a measuring tool, observation, and documentation. The analyzed using descriptive method. The results showed that the Braga Corridor segment 2 has provided visual psychic comfort and architecturally assisted thermal comfort in the morning and afternoon shadowing aspect, but for the comfort of the thermal beyond comfortable temperature zones.
\end{abstract}

Keywords: Sustainable Design; order; detailing architecture; site comfort.

\section{INTRODUCTION}

The principle of sustainability has become a global issue, in the context of architecture it is known as sustainable design. It is the basic philosophy of basic movements and organizations that focus on seeking the assurance of design, development and operation that is more environmentally responsible and responsive to society (McLennan, 2004). The core of sustainability philosophy is the realization of the linkage throughout the design aspects. In this case, there are 3 basic principles applied to the design process, namely: (a). Connectivity: design to strengthen the relationship between project, site, community and ecology. To minimize environmental changes and strengthen local characteristics. (b) Local Wisdom: adaptive consideration of the habits, needs and patterns formed on the environment and surrounding communities. (c). Continuity: design that can last up to future generations (Wiliama, 2007).

Connectivity between regions in a city can be assessed from the presence of corridors that form a linkage between the regions. The existence of a corridor is a connecting row, due to an order of masses that can form visual architectural design. The function of the corridor can develop as a communal area where the social interaction of the city community take place and contribute to the increase of the economic value of the city.

The city of Bandung itself has many cultural heritage buildings and some of them are located in corridors which is under the City of Bandung Regional Regulation, one of which is the Braga Corridor. This Corridor has been declared as a cultural heritage area that has historical and cultural value of Bandung City. The object of this research is the Braga Corridor, known internationally for decades as "Het meest Europeesche Winkelstraat van Indi" (Europe's most original shopping and business venue in Indonesia (Kunto, 1989).

Having its own distinctive features of a set of buildings with zero borders with 2-3 floor height in average and similarity in the composition of the buildings, as well as the pedestrian revitalization that places street furniture elements along the corridor. This makes the Braga Corridor in meet the criteria of community-based architecture, where "Identification of aspects of community-based architecture through methods with the view which defines and directs itself in the space given."(Marcos, 2012). It is this architectural identity which is presented by order and detailing facade that makes this corridor a favorite public space of the city community; a condition of a public space according to A. Bhatia (2015) who stated that public spaces provide pleasant experience (visual comfort) to the city community in conducting activities so that they create interaction between the environment and the community.

The typical characteristic of Braga area with the style of Indo Europeeschen Architectuur Stijl adapting the 4 season European building style with the tropical environment of Indonesia. This mixed 
style has been proved to provide internal and external comfort aspects of the buildings. However, the development of this Corridor is so rapid, that it has become a threat to the identity of the Corridor itself. Then how this Corridor identity sustain in the future and how to assure the existence of the Braga Corridor with its typical characteristics. How to generate a sense of belonging to the city community in this Corridor. The keyword is the comfort feeling of the city community. The consideration of these issues became the rationale of this research. This research is part of another research that has been planned, which serves to provide a positive and negative picture of the Braga Corridor from the aspect of sustainable design. The purpose of this research is to analyze the connectivity between architecture and comfort.

\section{LITERATURE REVIEW}

The criteria of sustainability describe three basic human needs: (1) .Environment, (2). Social and (3) Economy. One of the embodiments of sustainable design is the connectivity principle in establishing a relationship system between the site area with the society, the environment and the economy through local characteristic value. The design can serve as an integrated system between the macro to the micro of the region. The connectivity system in designing sustainability is divided into 3 groups: (a). the site connectivity to the region; (b). the site connectivity to the internal and surrounding sites; (c). the site connectivity to architecture (Wiliama, 2007). On the other hand, to identify corporate sustainability, there are a triple bottom line approach involving three dimensions mentioned by Yeang, (1996), namely: (1) Environment-measuring impact on resources such as air, water, emissions and waste; (2) Social-related to corporate governance, motivation, incentive, security, health and human resource development and behavior: (3) Economy-referring to the measurement of maintenance or improvement of success.

This study investigated the environmental dimensions on the comfort site associated with the architectural mass order. In this context, Architecture responds to the challenges in the provision of space from the side of the fulfillment of physical and psychic comfort function. While psychic comfort is more individual (subjective), physical comfort is more measurable. For example, we can observe the thermal comfort occurs due to the interaction of the physical environment and the individual that is the sensory sensor response to the temperature stimuli around. Additionally, we can find external climate parameters including solar radiation, air temperature, humidity, wind speed and rain (Karyono, 2016).
The Braga Corridor, the object of this study, is located in Braga road and segmented into 3 (three) segments. This Corridor is a cultural conservation area formed from the mass order of the architecture in some buildings observed to have adaptation detailing, known as adaptive reuse. It is the process of reusing old sites or buildings for purposes other than what those were built or designed for as well as their approach to conservation practices. This process believed to be one solution to revive a historic area and raise a sense of belonging to the city community. (Cantacuzino, S., 1989). Have believed, the adaptive reuse will help maintain the potential of the city without losing the identity of the buildings in it. It is commonly known that the Braga Corridor has adapted itself to modern architecture and different lifestyles for several decades. Currently, this corridor is still able to attract many visitors, and expects more visitors to come. Plevoets, et al (2011) suggest that the implementation of the adaptive reuse can be performed by employing some strategic approaches to direct the development of conservation area towards sustainability, they are: (1) Building inside; (2) Building upon; (3) Building around; (4) Building on the side; (5) Recycling materials; (6) Adapting new functions; (7) Adapting building style.

\section{METHODOLOGY}

This study involved two teams of the researchers performing different tasks. One team distributed the questionnaires as well as interviewed the participants and the other observed, measured thermal data and documented the site. The object of study was the Braga Corridor segment 2 known as Braga Panjang. As mentioned earlier, Braga road is divided into 3 (three) segments. The road width itself is estimated tobe approximately 7.5 meters and pedestrian approximately_2 meters wide in each side. However, there is a difference of axis of Braga road on the North side ( $3^{\text {rd }}$ segment $)$ and South $\left(1^{\text {st }}\right.$ segment). The object of this research focused on the 2nd segment known as "Braga Panjang". This segment compared to other segments has a length of +398 meters, perfectly formed as a corridor. See figure 1 .

The scope of the study was the environment aspect in sustainable design with shading and breezeway variables. Those aspects were analyzed in the contexts of the principles of sustainable design, focused on connectivity site to architecture in order to identify how the building corridor makes the micro climate and to find out the community's perspectives on the comfort feeling from the thermal and visual aspects. The respondents involved in this study were 
the visitors of the corridor visiting the site by the time our teams collected the data. These people were selected by purposive sampling, meaning that they were selected randomly by the researchers. The period of observation was 2 days at the weekdays and 2 days at the weekend. The sample time period was selected at the time when the sun's intensity is considered to be high during the dry season in Bandung.

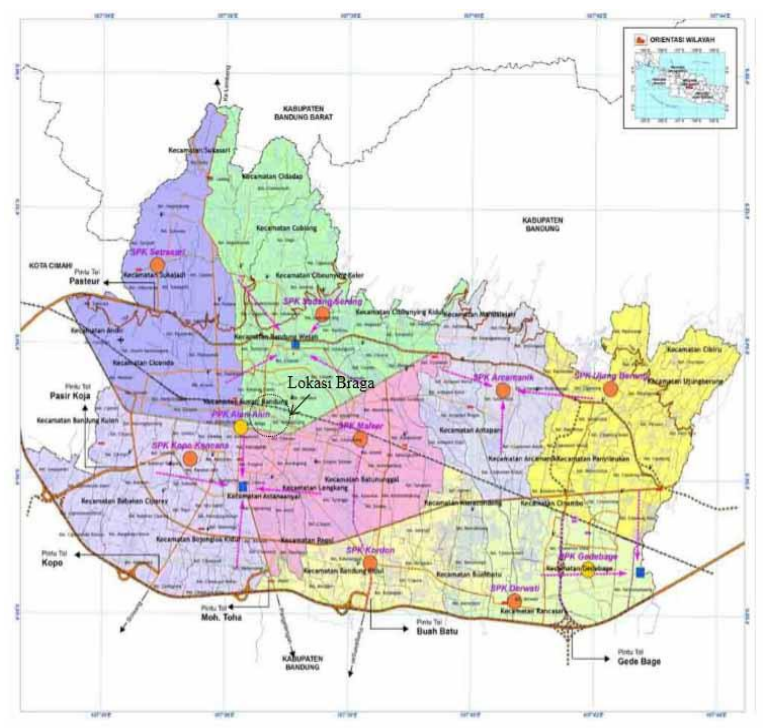

(a)

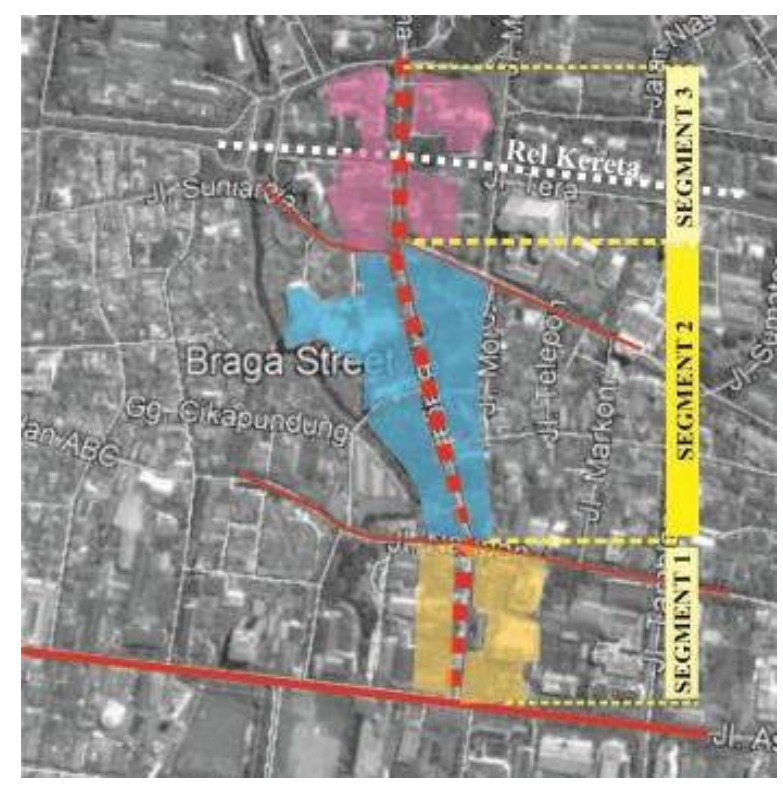

(b)

Fig. 1. (a) Braga Location; (b) Braga Corridor Segmentation (Source: (a) RTRW kota Bandung; (b) Googlemap 2017,edited by author).

The time of the observations were scheduled at 08:00 to $10: 00,12: 00$ to $14: 00$ and $15: 00$ to $17: 00$. Ten sample visitors were targeted in each day. The observation data were collected through field survey, aided documentation and interviews. Observation with research instrument included thermometer, anemometer and hydrometer to get thermal data. The data were measured at 3 time periods simultaneously and the questionnaires were distributed at 6 different spot in $2^{\text {nd }}$ segment. Three times measurements in each place to support the analysis. The simulation program was created using Sketchup for shading and Autodesk flow for breezeway. The collected data were analyzed using mixed method approach applying descriptive analysis.

\section{RESULTS AND DISCUSSION.}

Some buildings on Braga Street have undergone a change of facade that made it leave the image of the original Braga area. The buildings located along the Braga Street have an Indo Europeeschen Architectuur Stijl built around the 1910s-20s (Kunto, 1985). This style has a special typology and character that is the adaptation of the four seasons of European origin buildings with the footprint tropical building. According to Santoni (2014), a group of typologies seen on the buildings in the area of Braga are single buildings, series, double look, ensemble and modern. Another survey results identified 25 buildings on the East side and 22 buildings on the West side. The total building on the 2nd segment of Braga corridor is 47 buildings. However, due to the uniqueness of typology in some building series that have 2-8 units in one roof, and if we identify only units of the shop houses, shops and offices then there will be 74 units in total.

In addition to the old buildings, there are also new buildings that follow the guideline area or not, spread. The total of the new buildings are 17 units (23\%). The visual appearance of the Corridor is built from the character of the Indo Europeeschen Architectuur Stijl, although some have changed but the strong character of the style is still there. The identification result states that the horizontal and vertical elements of the buildings are not formed monotonically and the variety becomes the guideline of the area and the characteristic of the heritage architecture. By analyzing the elements, we can get the information of the functions of the buildings. These building commonly have 3 (three) separated parts of the facade representing displacement or transition between the lower, middle and top. Window elements accompanied by a canopy and a vent contribute to the function of interior comfort of the building in addition to the aesthetics for the exterior of the building. See figure 2 . 


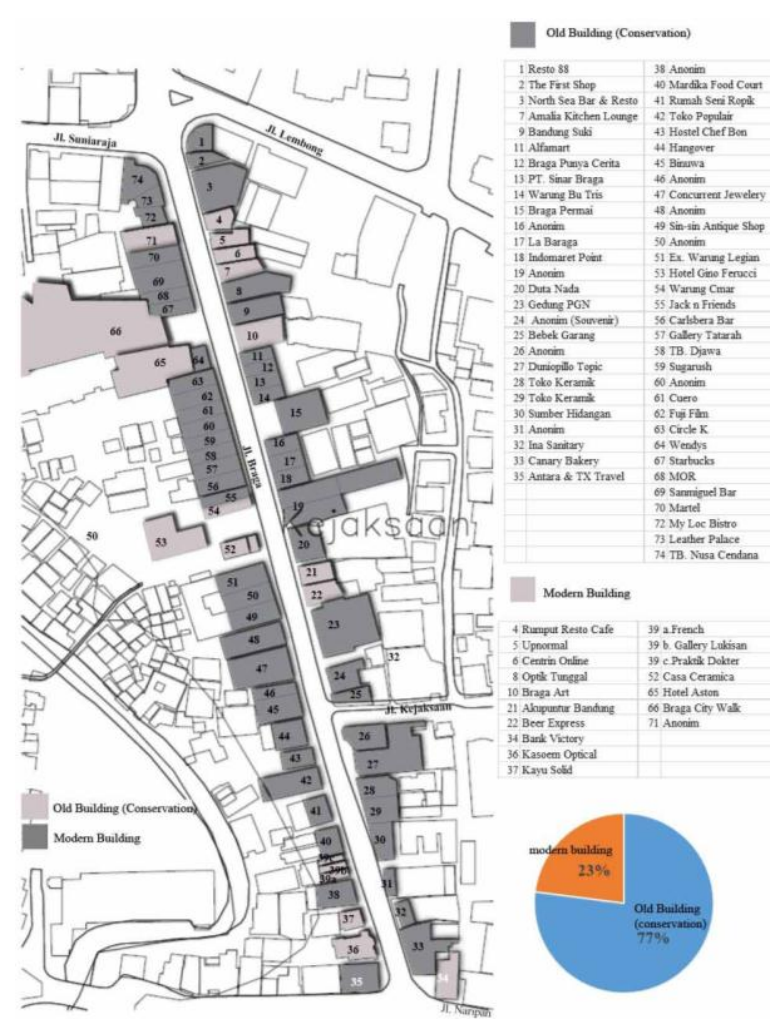

(a)

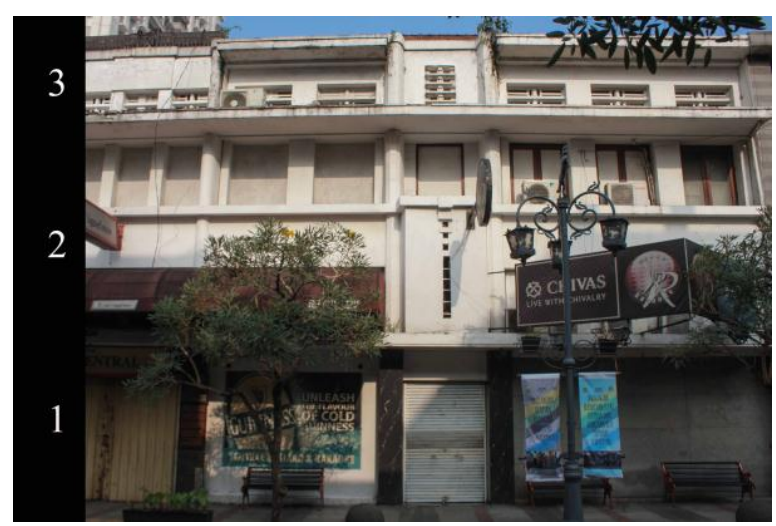

(b)

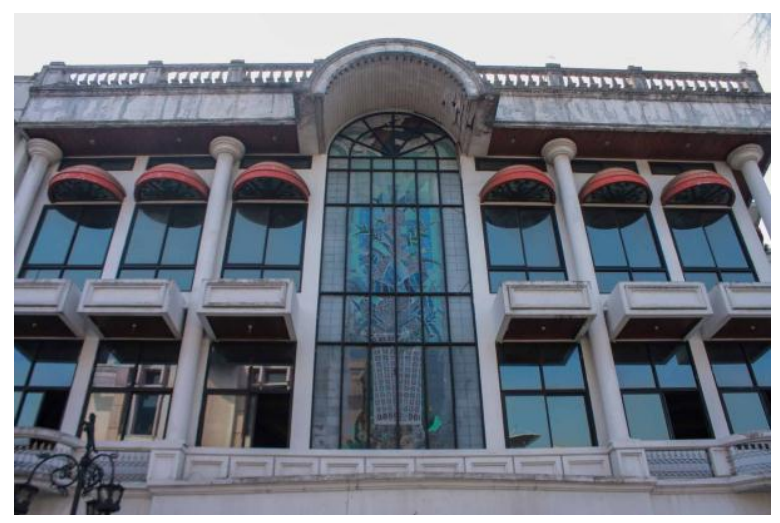

(c)

Fig. 2. (a) The spread of the buildings in Braga Corridor; (b) Old Building Tipology; (c) Modern Tipology (Source: (a) Peta Garis Bandung, 2010 edited and (b),(c) author documentation).
The uniqueness of the corridor in segment 2 (two) is from the perception of space formed from the proportion of Height (H) and Distance (D). Mc.Clusky (1979) explained how buildings envelope through the height of the field with the width of space between the building's envelopes can give or create a certain impression and perception. The Braga Corridor is formed with a 1: 1 ratio that makes this Corridor. A 1: $1 \mathrm{H} / \mathrm{D}$ ratio provides a $45^{\circ}$ viewing angle that allows the observer to see the details and facade of the building as a whole, as shown below.

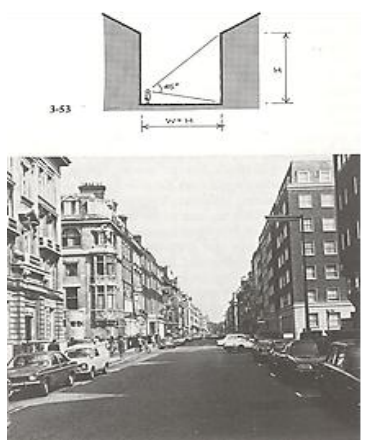

(a)

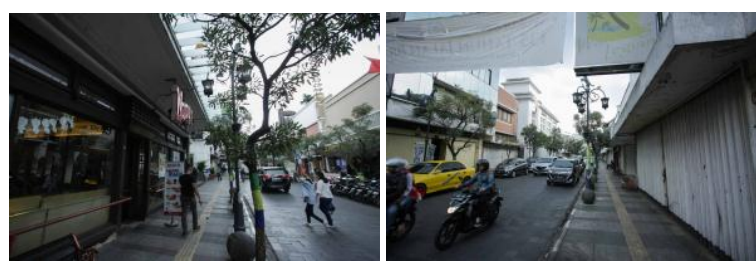

(b)

Fig. 3. (a) H:D Rasio 1:1 (Mc.Cluskey, 1979); (b) Spatial Ratio Braga

The Braga Corridor provides an architectural setting of heritage buildings with short inter-building distance. It helps the occurrence of imagery between buildings that can be interpreted that this site provides an intimate space perception and allow the visitors to enjoy visual street detail of the buildings. The Corridor itself has the length of +398 meters that offers an opportunity to the visitors to go through a diverse space experience and background options for the city community's activities.

\section{Site to Architecture (or Architecture to Site)}

Environmental dimension suggests that an area will not burden the surrounding environment, and provide minimal comfort if an appropriate microclimate is formed. The role of architecture in the Braga Corridor provides an influence in the formation of microclimate in the region. The Braga Corridor exhibits an architectural setting of heritage buildings with short inter-building distance. It helps the 
occurrence of imagery between buildings with each other, so the road will be shady in the morning as well as in the afternoon. In this research, we tried to simulate the imagery with Sketchup software which can be seen in the picture below with coordinate data Latittude of $6^{\circ} 55^{\prime} 2.76$ "S, and Longtitude $107^{\circ} 36^{\prime}$ 33.58" E (Google map, 2017) with world agreement time zone for Indonesia: Bandung GMT +07.00.

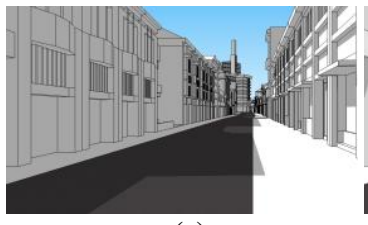

(a)

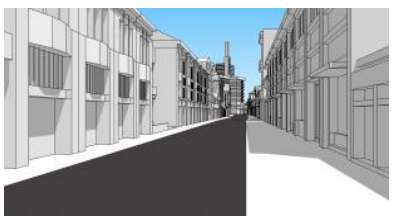

(b)

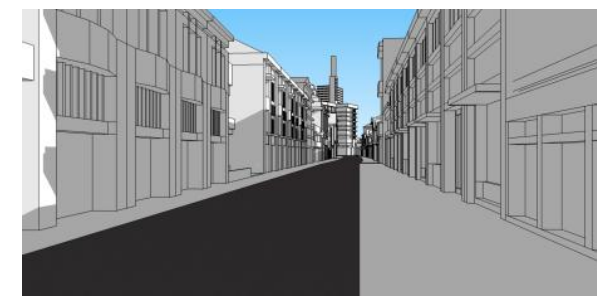

(c)

Fig. 4. Shading Simulation by Sketchup software. (a) Morning period at 09.00, (b) Afternoon period at 13.00, (c) Evening period at 16.00 (in August, left-east side, right-west side)

The image above shows the building imagery in the morning and afternoon. The height of the building in this Corridor helps to cope with direct sunlight in the morning and afternoon time, this interpretation is also supported by the temperature data measured in this Corridor. The height of the building provides a shadowing effect that will impact the reduction of solar radiation in the region (Karyono, 2016). At noon when the sun is at the top of the track, it gives the impact of direct sunlight that leads to the corridor. The position of the sun at the top results in a shrinking of the imaginary area which can lead to fields on the surface of the land and buildings, obtaining solar radiation directly.

The results of the comfort survey using measuring tools for thermal parameters included the temperature, wind speed and humidity. They were measured in each period of morning, noon, afternoon within 4 (four) days consecutively, identifying the microclimate that occurred in the Braga Corridor. The following table 1 provides information on the measurement data and the average of 3 parameters in the field.

From the data, it is shown that the overall average data generated of the temperature was $30,7^{\circ} \mathrm{C}$, the wind speed was $0,6 \mathrm{~m} / \mathrm{s}$ and humidity was $40 \%$. The results of these measurements indicated typical humid tropical climate with relatively high air temperature characteristics and low wind speed. Low wind speed results in high humidity in the region. In this case the humidity is identified $40 \%$ which according to BMKG "decreased air humidity

Tabel 1. Thermal Data at Sample periode-August 2017,

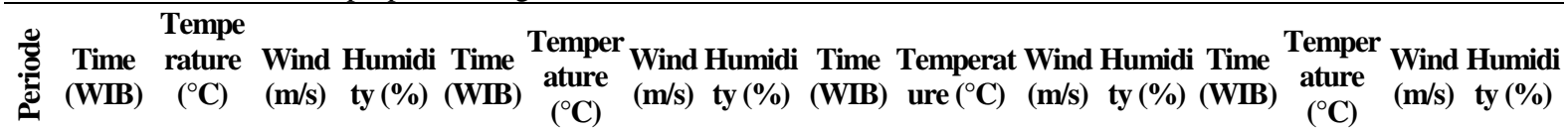

\begin{tabular}{|c|c|c|c|c|c|c|c|c|c|c|c|c|c|c|c|c|}
\hline & \multicolumn{5}{|c|}{ Friday,18-08-2017 } & \multicolumn{3}{|c|}{ Saturday, 19-08-2017 } & \multicolumn{5}{|c|}{ Monday, 21-08-2017 } & \multicolumn{3}{|c|}{ Wenesday, 23-08-2017 } \\
\hline & 8.31 & 24.83 & 0.3 & 59.23 & 9.30 & 26 & 0.6 & 55 & 11.08 & 28 & 0.2 & 43 & 9.04 & 27.2 & 1.53 & 47.1 \\
\hline & 8.23 & 23.23 & 1.7 & 54.86 & 9.39 & 27 & 1.1 & 53 & 11.06 & 30 & 0.9 & 36 & 9.12 & 28 & 1.13 & 48.3 \\
\hline & 9.14 & 27.1 & 0.13 & 52.13 & 9.49 & 29 & 0.2 & 49 & 11.27 & 31 & 1 & 31 & 8.28 & 27.3 & 0.57 & 46.1 \\
\hline & 9.56 & 30.26 & 0.26 & 43.37 & 9.46 & 29 & 0.7 & 51 & 11.23 & 34 & 0.6 & 29 & 8.53 & 31.2 & 1 & 45.5 \\
\hline & 9.37 & 27.9 & 0.83 & 50.93 & 9.55 & 30 & 0.6 & 49 & 11.34 & 30 & 1.8 & 35 & 8.39 & 27.5 & 1.23 & 51.2 \\
\hline & 9.4 & 28.23 & 1.83 & 46.76 & 9.58 & 30 & 0.2 & 47 & 11.39 & 32 & 0.6 & 35 & 8.45 & 27.3 & 1.83 & 45.3 \\
\hline & Average & 26.93 & 0.842 & 51.21 & & 28.5 & 0.567 & 50.67 & & 30.83 & 0.85 & 34.83 & & 28.08 & 1.215 & 47.25 \\
\hline \multirow{7}{*}{ 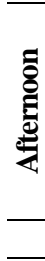 } & 12.52 & 33.1 & 1.3 & 34.3 & 13.26 & 33 & 1.8 & 44 & 14.14 & 31 & 0.1 & 27 & 12.44 & 35 & 0.1 & 30.06 \\
\hline & 12.48 & 31.5 & 0.1 & 36.5 & 13.24 & 30 & 2.1 & 45.1 & 14.10 & 31 & 0.5 & 31 & 12.49 & 35.4 & 0.3 & 31.3 \\
\hline & 12.26 & 31.2 & 0.3 & 35.1 & 13.00 & 31 & 0.9 & 44 & 13.5 & 32 & 1.7 & 30 & 12.39 & 34.8 & 0.2 & 29.8 \\
\hline & 12.42 & 33.2 & 0.1 & 37.1 & 13.04 & 31 & 0.2 & 46 & 13.55 & 33 & 0.2 & 25 & 12.35 & 33.5 & 1.17 & 30.9 \\
\hline & 12.33 & 30.5 & 0.8 & 36.5 & 15.07 & 31 & 0.4 & 46 & 14.28 & 34 & 1.3 & 22 & 12.28 & 34.8 & 1.1 & 30 \\
\hline & 12.36 & 30.8 & 0.7 & 36.03 & 15.04 & 30 & 0.7 & 48 & 14.33 & 31 & 0.5 & 27 & 12.35 & 35.4 & 1.07 & 29.2 \\
\hline & Average & 31.72 & 0.55 & 35.92 & & 31 & 1.017 & 45.52 & & 32 & 0.717 & 27 & & 34.82 & 0.657 & 30.21 \\
\hline \multirow{7}{*}{ 量 } & 15.25 & 30.5 & 0.1 & 45.6 & 16.12 & 30 & 0.3 & 46 & 15.44 & 30 & 0.4 & 34 & 15.11 & 35 & 0.7 & 29.6 \\
\hline & 15.22 & 30.03 & 0.26 & 44.8 & 16.16 & 30 & 1.4 & 49 & 15.38 & 30 & 0 & 33 & 15.15 & 33.8 & 0.1 & 32.1 \\
\hline & 15.04 & 30.4 & 0.1 & 44.1 & 16.3 & 29 & 0.2 & 49 & 15.17 & 32 & 0.1 & 29 & 15.36 & 32.7 & 0.06 & 35.4 \\
\hline & 15.18 & 31.46 & 0.1 & 45.36 & 16.32 & 29 & 0.2 & 49 & 15.22 & 31 & 0.1 & 30 & 15.19 & 32.03 & 0.7 & 32.9 \\
\hline & 15.10 & 29.8 & 0.3 & 45.6 & 16.4 & 29 & 0.2 & 50 & 15.09 & 32 & 0.5 & 28 & 15.28 & 32.23 & 0.3 & 34.1 \\
\hline & 15.12 & 31.67 & 0.33 & 43.6 & 16.37 & 29 & 0.4 & 51 & 15.03 & 32 & 0.3 & 29 & 15.23 & 31.8 & 0.2 & 36.3 \\
\hline & Average & 30.64 & 0.198 & 44.84 & & 29.33 & 0.45 & 49 & & 31.17 & 0.233 & 30.5 & & 32.93 & 0.343 & 33.4 \\
\hline
\end{tabular}


happened during the dry season"(Pikiran Rakyat, 2017). In addition, there are possible factors causing low humidity, i.e the lack of soil surface so that evaporation of water from the soil is very low. This possibility makes the lowest water content in the air. Theoretically, overall average data can complicate the achievement of the thermal comfort of humans in the place. Braga corridor position which has North-South axis, does not benefit to catch the wind circulation of Bandung City which dominated in August is from east to southeast (BMKG, 2017). The wind simulation is shown in figure 5 .

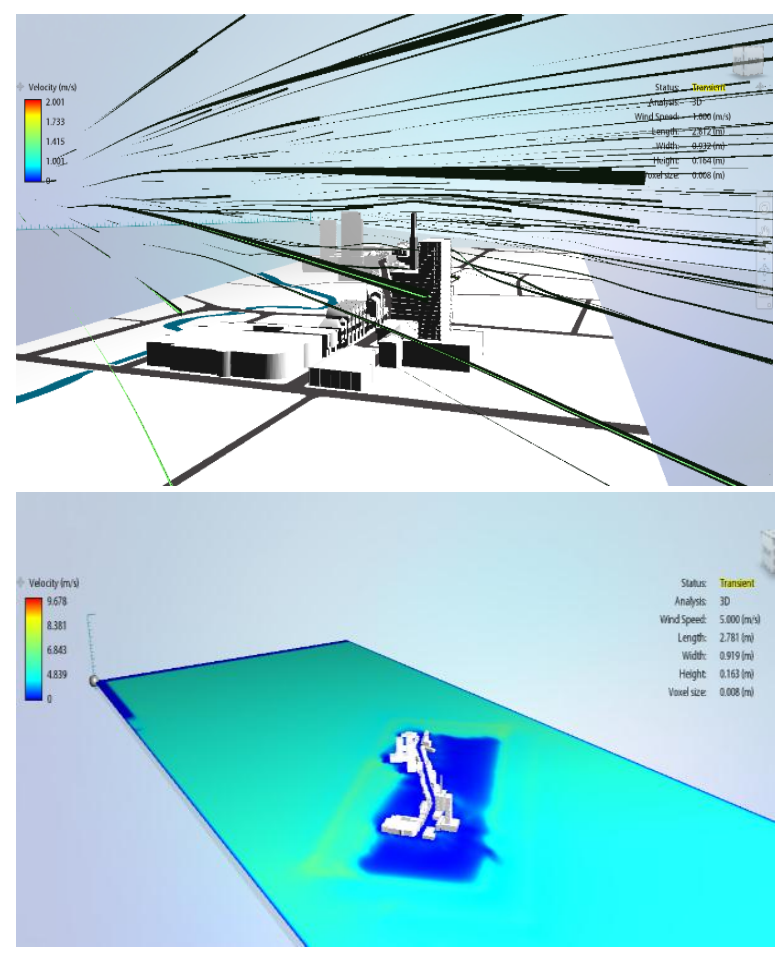

Fig. 5. Wind Simulation by Autodesk Flow Program

The picture above illustrates the direction and position of the wind in the Braga corridor from above the building and does not enter into the corridor. This is due to obstruction of the wind by the buildings in the West and East sides. The spectral simulation data identifies the average wind speed below $1 \mathrm{~m} / \mathrm{s}$, the data is in accordance with the results of field measurements periodically. The measurement data in the field support the simulation created in the program. It was also gathered the information that the average temperature of $30,7^{\circ} \mathrm{C}$, wind speed $0,6 \mathrm{~m} / \mathrm{s}$, and air humidity is $40 \%$.

The results of the analysis provide evidence that the microclimate of the Braga Corridor in thermal comfort was considered to be in "beyond the comfort zone". Karyono (2016) mentioned that Highland Cities like Bandung with daily air temperature range at $18^{\circ} \mathrm{C}-30^{\circ} \mathrm{C}$, while the perceived comfortable temperature is estimated to be at $23,9^{\circ} \mathrm{C}$. This condition is exacerbated by the type of concrete pavement material on pedestrian and stone material on the road as well as improper vegetation planting, causing the solar radiation heat to fall on the hard surface to be absorbed, raising the material temperature.

Connectivity architecture and thermal comfort in this corridor is to discuss about the relationship between synergy between the microclimate and human needs for comfort. Corridor is a public space that is formed due to the mass structure of buildings that lined up and give impact to the microclimate of the region. Braga region is located in a humid tropical climate zone where the basic principle in designing architecture in this zone is how to reduce air temperature and radiation in buildings and areas. According to Karyono, 2016 "temperature reduction can be done by reducing heat gain" heat gain "that falls into the building or area. As for the reduction of solar radiation can be done by giving shading (shading) to the building or area. The next basic principle is to "remove the heat" by providing adequate openings for cross-ventilation."

In segment 2 of Braga corridor, it can be seen from the perspective of the comfort of the corridor hall that formed. The ratio of $\mathrm{H} / \mathrm{D}=1$ : 1 not only makes the atmosphere of the corridor intimate and allows the visitor to see the façade details of the building, but there are other important aspects, especially in the design of humid tropical climate architecture. This space scale provides a solution for the comfort of space of each building unit. The formation of the unit and the height of the building and the position of windows within the Braga area, has been designed in such a way in cross ventilation aspects especially in older buildings. Ancient architects had predicted the direction of the wind. As a result the wind is blockaded by the building towards the corridor, but on the other hand, the wind is directed to enter the building, see figure 6 .

The opening/ventilation of the old building in the East and West direction, it is very important to catch the wind and design the wind circulation in and out of the building (figure 6). Another impact on the outer climate of the Braga corridor is in another aspect of reducing direct solar radiation through building imagery and the principle of heat dissipation as it is an open area. Architecturally, some buildings have provided solutions to provide shadow effects by providing canopy, fin and subtractive on shapes. It can be seen some difference of settlement to reduce architectural solar radiation in this corridor, see figure 7. 


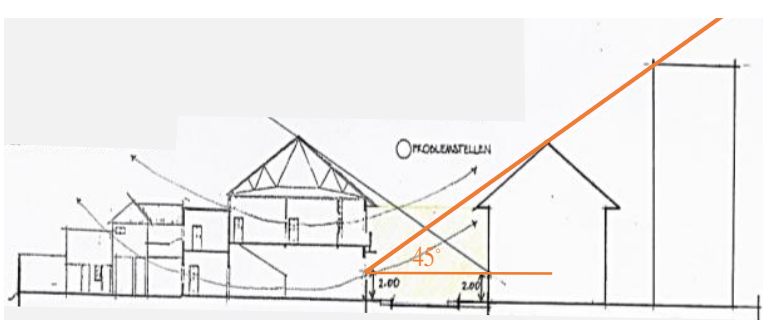

Fig. 6. Wind Flow Simulation sketch (Source: David, 2017 edited by author

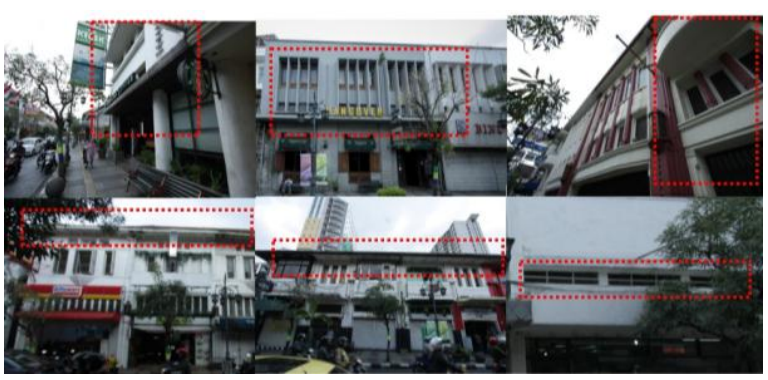

Fig.7. Detailing Façade Old Building

The picture above illustrates the completion of the archives through horizontal fins for the effect of imagery on the plane of walls and openings. Solution of vertical fins for glass openings. The building features roof eaves and balconies, for the reduction of heat-absorbing solar heat. Openings of transparent planes that slightly slows down solar radiation. Architectural differences can be seen in old and modern buildings. Figure 8 processed architecture of modern buildings. The selection of materials that are massive and thick, helping to stabilize the internal temperature of the building. Selection of colors with bright gradations, reducing the occurrence of heating effects in the building and on the microclimate corridor.

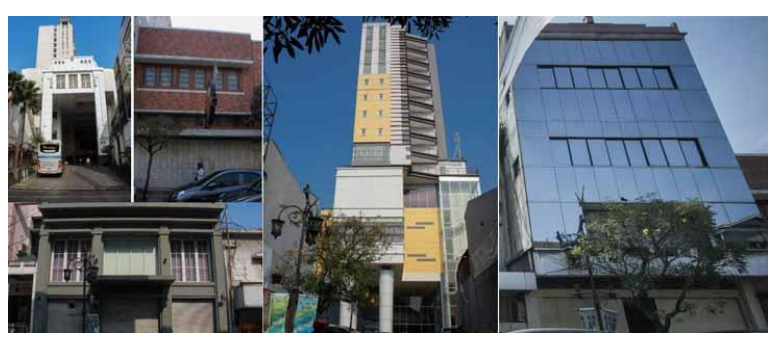

Fig. 8. Modern Building Façade

Modern buildings in the area of Braga, architecturally adopt vertical and horizontal line elements that exist in older buildings (heritage). The obvious difference is the use of more transparent field materials in the building façade and dark gradation colors. The impact on the microclimate of corridors and in buildings is the rise in temperature. The transparent nature of the material and the dark color that can conduct, reflects direct sunlight radiation. The heat that was poured into the room could not penetrate the glass and was eventually trapped.

The thermal discomfort of this corridor, more influenced by other factors. For example air pollution due to vehicles, emissions of gas emissions and rising earth temperatures due to greenhouse effect. This process of course needs to be responded back by the old building, not just rely on the original details. In Figure 9, the old adaptation of the building to the thermal aspect is shown by providing modern canopy as an added effect to slow the absorption of heat.

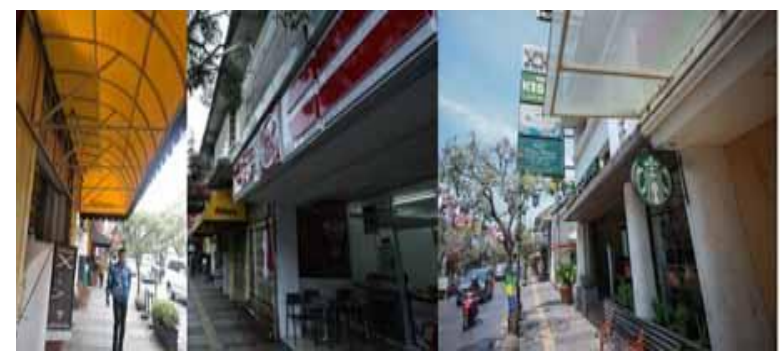

Fig. 9. Adaptation Process in Old Building for Increase the Comfort Zone

In terms of thermal comfort, the old building of Braga corridor is more able to adapt the thermal rise of the area compared to the new building. But of course, this adaptation process needs to be controlled so that the visual identity of the old building is not disturbed.

\section{Individual Comfort Assessment of Respondents}

Basically, each individual has a different comfort zone and perception. This study attempts to identify the perception of the Kota community on comfort in the Braga corridor. Question on the questionnaire for the respondent is "Is the Corridor Braga can be categorized as a comfortable area by air? The results of the questionnaire can be seen in figure 10 (left). To reinforce the data, the questionnaire was given the question which was the reason for the inconvenience in Braga corridor according to the respondent. See figure 10 (right).

The pie charts above present the results of the questionnaire data analysis. The questionnaire required the respondents' to assess the Braga Street by putting it into the category of thermal comfort or not. The green piece of the chart shows the percentage of the respondents who put the street into thermal comfort, and the blue piece for NOT thermal comfort. As seen from the chart, most respondents agreed that Braga Street is not under thermal comfort category. In other words. The street is considered to be uncomfortable based on respondent's assessment. The pie 
chart on the right side provides information on the reasons of the categorization from the respondents. It is shown that the respondents who perceived that the Braga Street was "comfortable" mostly were visitors visiting the street in the morning, and they used the vegetation along the corridor and the time to visit in the morning as the reasons. They claimed that the average temperature of $29^{\circ} \mathrm{C}$ is felt more comfortable than the time during the midday and afternoon. On the other hand, the respondents who argued that the street was "uncomfortable" used the amount of pollution and vehicles in the site as the reasons. Therefore, in order to improve the comfort in this corridor, in addition to the completion of the architectural elements, it is needed some significant settlement in other aspects as well such as the reduction of the intensity of private vehicles in order to reduce the traffic and vehicle emissions.

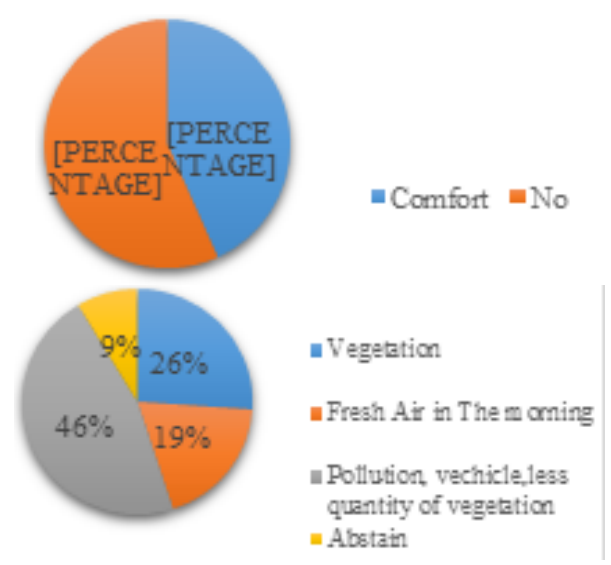

Fig. 10. Questionnaire data analysis results regarding the comfort of Braga Street and their reasons

From the data of questionnaire, Braga physical comfort viewed from the thermal side was considered to be outside the comfort zone. The question in the questionnaire to assess the participants' perception on the psychic or visual comfort of Braga Street was "What is the most interesting object in the Braga corridor?", see figure 11.

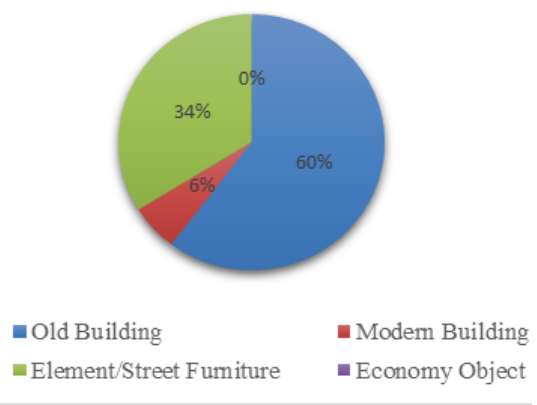

Fig. 11. Questionnaire data analysis on the interesting objects in Braga.

\section{CONCLUSION}

The Braga Corridor (segment-2) was prepared as an economic zone as one of the tourist attraction areas in the city of Bandung. The old building's typology with style in Indo-Europeeschen Architecture Stijl provides an interesting space experience for the city community. The order of the masses lined with the typical details of the horizontal lines, making a favorite background of the city community. In fact, the details do not function only aesthetically but also for the comfort of the buildings' internal thermal. In visual comfort, this Corridor has provided an interesting thing as a place to interact. The orientation of the west and east direction of the mass and the scale of space formed by a ratio of $1: 1$, dominated 23 storey buildings, creating a shading zone in the morning and afternoon. But when the sun's path is at the peak (day period), the Corridor escapes from the shades and gives effect that raises the temperature around the corridor compounded by the high intensity of vehicle pollution. The openness and formation of the Corridor allow the wind to enter and lower the heat. However, the direction of the city wind is not parallel with the corridor so that the blown of the wind in environment was blocked by buildings on the west and east sides. Despite the fact, the wind direction is advantageous for space thermal comfort in the old buildings because it gives the effect of cross ventilation evenly for thermal comfort, but the Corridor is outside the comfort zone. The architectural and architectural formations, however, help the city community to stay in touch in this Corridor. This research is a pilot project of a study conducted to investigate the strategy of the green building design in order to optimize the application of sustainable design connectivity principle in conserved corridor areas of Bandung.

\section{ACKNOWLEDGMENT}

Acknowledgements aimed at the MENRISTEK DIKTI which provides funding to do this research. To LP2M ITENAS for the support and Bandung Heritage who provided the secondary field data

\section{REFERENCES}

Bhatia, A. (2015). Placemaking; Creating aplace of sense and sense of place. Architecture Research Paper.

Cantacuzino, S. (1989). ReArchitecture: New Building/Old uses, New York, Abbeville Press Publisher. 
Karyono. T. H. (2016). Bentuk, Teknologi, Kenyamanan dan Penggunaan Energi, Arsitektur Tropis, Penerbit Erlangga.

Kunto, H. (1985). Wajah Bandoeng Tempoe Doeloe, Granesia.

Mc.Cluskey, J. (1979). Road Form and Townscape, Nichols. Pub. Co, New York.

Mc.Lennan, J.F. (2004). The Philosophy of Sustainable Design; the Future of Architecture, Ecotone LLC.

Peraturan Daerah Kota Bandung No.19 tahun 2009 Tentang Bangunan Cagar Budaya.

Peraturan Daerah Kota Bandung No.18 Tahun 2011 Tentang Rencana Tata Ruang Wilayah Kota Bandung (RTRW).

Plevoets, B. \& Cleempoel. (2011). Adaptive reuse as Strategy Towards Conservation of Cultural
Heritage; a literature review, In terme, C.B.a.L.B.C. (ed) Structural Studies, Repairs and Maintanance of Heritage Architecture XII, Italy, WIT Press.

Santoni. (2014). Transformasi dan Tipologi Bangunan Indoeuropeeschen Architectuur Stijl Kawasan Braga, Bandung, E-Journal Graduate Unpar Part D-Architecture, 1(2), 2014, pp.2355-4274.

Wiliama, D.E. (2007). Sustainable Design, Ecology, Architecture and Planning, John Willey \& Sons. Inc.

Yeang, K. (1996). The Skyscraper Bioclimatically Considered; London; Academy Editions

http://www.pikiran-rakyat.com/bandung-raya/2017/ 08/01/bmkg-pada-malam-hari-suhu-di-kotabandung-lebih-dingin-406459 accessed on 10 January 2018. 